\title{
Gorontalo
}

Journal of Government and Political Studies

Volume 3 - NO. 1 - April 2020

P-ISSN: 2614-2120 E-ISSN: 2614-2104

\section{Kehadiran Kartu Smart Madani dan Kartu Identitas Anak sebagai Program Pengembangan Smart City di Kota Pekanbaru}

\author{
Rizky Haifulloh ${ }^{1}$ \\ Eko Priyo Purnomo² \\ Lubna Salsabila ${ }^{3}$ \\ Department of Government Science, Faculty of Social and Political Science ${ }^{1}$, \\ Universitas Muhammadiyah Yogyakarta \\ Departement Of Government Affairs And Administration, \\ Jusuf Kalla School of Government ${ }^{2}$, Universitas Muhammadiyah Yogyakarta \\ 1ikiuser539@gmail.com 2eko@umy.ac.id 3lubna.salsa@gmail.com
}

Received:December 28, 2020; Revised:April 07, 2020

Accepted: April 07,2020

\begin{abstract}
This study examines how the presence of "Madani Smart Card" and "Child Identity Card" which is a program rather than the development of smart cities in the city of Pekanbaru. Smart city which then emerged as one of the hot discourses was discussed in the discourse on sustainable development, which in this case will be applied in every city in all corners of the world. The author then in this study uses qualitative research methods, where data and field findings will be presented descriptively. By measuring how the causes of the two smart cards are presented, the author tries to find an understanding of any urgency that arises or real problems faced by Pekanbaru City. So in the theoretical framework the writer uses Dye's theory in analyzing the process of program formulation or termination and policies taken by the government, in this case the Pekanbaru City government. The findings which were then obtained by the authors through this research are that after referring to the Pekanbaru City Medium Term Development Planning 2017-2022 document, finally the author can pick up or know the backrest and framework that presents the two smart card program. So that from this study the authors can get the following results: First, theoretically the presence of the two smart card program will have a good impact on the ability or literacy of technology and information usability in the city of Pekanbaru. Second, the implementation of the two smart card program would have been right on target if it referred to one of the problems facing the city of Pekanbaru. Third and finally, although the presence of this program is good in some respects, on the other hand there are holes that should be prioritized to be patched actually by the city government through its innovations, one example of how the poor or marginal in the city can be utilized through the concept of smart city (smart city) and its development there.
\end{abstract}

Keywords: Smart City; Madani Smart Card; Child Identity Card

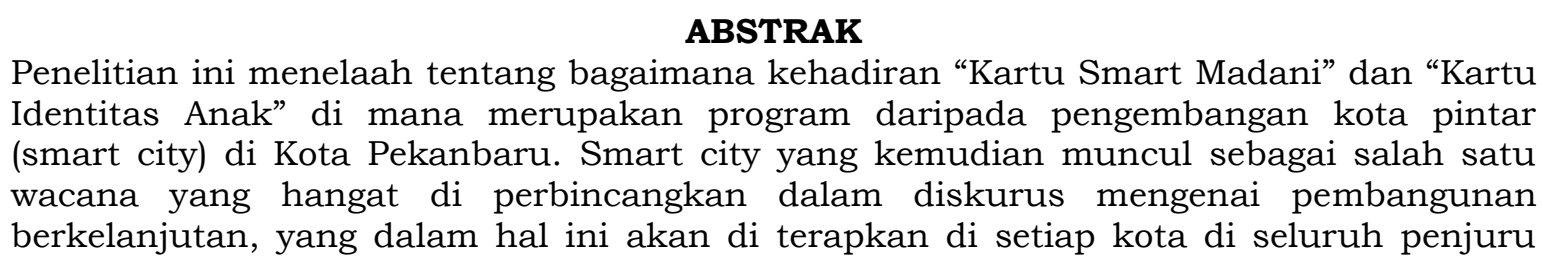


dunia. Penulis kemudian dalam penelitian ini menggunakan metode penelitian kualitatif, di mana data dan hasil temuan lapangan akan di sajikan secara deskriptif. Dengan menakar bagaimana penyebab dihadirkannya kedua kartu pintar tersebut, penulis mencoba untuk mencari pengertian dari setiap urgensi yang muncul atau permasalahan yang nyata di hadapi oleh Kota Pekanbaru. Sehingga dalam kerangka teoritis penulis memakai teori dari Dye dalam menganalisis proses perumusan atau pemutusan program serta kebijakan yang diambil oleh pemerintah, dalam hal ini pemerintah Kota Pekanbaru. Temuan yang kemudian di dapatkan oleh penulis lewat penelitian ini adalah setelah merujuk pada dokumen Rancangan Pembangunan Jangka Menengah Kota Pekanbaru 2017-2022 akhirnya penulis bisa mengambil atau mengetahui sandaran serta kerangka kerja yang menghadirkan program dua kartu pintar tersebut. Sehingga dari penelitian ini bisa penulis dapatkan hasil sebagai berikut: Pertama, secara teoritis kehadiran program dua kartu pintar ini akan berdampak baik terhadap kecakapan atau literasi teknologi dan dayaguna informasi di kota Pekanbaru. Kedua, pengimplementasian daripada program dua kartu pintar ini kiranya sudah tepat sasaran jika merujuk kepada salah satu permasalahan yang dihadapi kota Pekanbaru. Ketiga dan terkahir, walaupun kehadiran program ini dalam beberapa hal baik adanya, namun di sisi lain terdapat lobang yang seharusnya lebih didahulukan untuk ditambal sebenarnya oleh pihak pemerintah kota melalui inovasi-inovasinya, salah satu contohnya bagaimana masyarakat miskin atau marginal di kota tersebut dapat didayagunakan lewat konsep kota pintar (smart city) dan pengembangannya di sana.

Kata kunci: Smart City; Kartu Smart Madani; Kartu Identitas Anak

\section{PENDAHULUAN}

Dalam kurun waktu satu dekade belakangan kota-kota disetiap penjuru dunia tengah digencarkan dengan berbagai isu pembangunan, utamanya bagaimana pembangunan yang berkelanjutan. Lewat hal tersebut, kota kemudian dinilai tidak serta-merta hanya sebagai lapangan atau tempat beradanya berbagai industri dan serta roda administrasi daerah. Akan tetapi, kota yang dimaksud dalam kampanye pembangunan berkelanjutan yang digencarkan oleh UNDP adalah kota yang tidak hanya sebagai ladang perekonomian belaka, sebaliknya kota juga sekarang dimaksudkan sebagai tempat tinggal manusia yang sehat, nyaman dan seturut dengan itu ramah lingkungan. Konsep tentang sebuah kota yang berkelanjutan dalam pembangunannya pun akhirnya diaplikasikan saat ini dihampir seluruh kota di Indonesia. Adalah konsep smart city atau dalam bahasa Indonesia disebut dengan berbagai macam istilah kota pintar, kota cerdas, ataupun kota madani menjadi jantung dari arah pembangunan setiap kota di dunia saat ini, seturut dengan itu di Indonesia (Suhendra, 2017).

Di mana smart city kemudian telah menjadi sebuah program yang kiranya wajib bagi setiap kota di Indonesia. Meskipun begitu konsepsi tentang smart city di Indonesia sendiri masihlah begitu beragam, sehingga menimbulkan perbedaan-perbedaan dalam hal penerapan pembangunan smart city disetiap daerahnya. Hal tersebut sebagaimana menurut Suhendra (2017) disebabkan oleh tidak adanya sebuah regulasi sampai dengan hari ini, yang mana mengatur jalannya penerapan smart city, lebih jauh menjadi kerangka kerja atau pedoman yang definitif bagi setiap pemimpin daerah untuk secara lebih jelas mengatur tentang program-program perwujudan smart city sendiri.

Adalah Bandung dan Surabaya yang kiranya menjadi kota terdepan dalam hal kemajuan pengaplikasian smart city di Indonesia (Akbar, 2018). Bandung 
yang mendapatkan berbagai macam prestasi dalam hal pengembangan smart city kemudian lewat ratusan aplikasi yang didayagunakan mampu menarik partisipasi aktif dari warga kota untuk ikut aktif dalam hal monitoring dan pemeliharaan kota, selain itu dengan cara menyalurkan pendapat mereka lewat aplikasi-aplikasi pendukung yang disediakan oleh pemerintah kota Bandung. Begitu pula dengan Surabaya, dengan label kota metropolit yang mana penduduknya tercatat hampir mencapai angka dua juta orang, maka sebagai kota percontohan sendiri dengan segelimang prestasinya Surabaya dikira layak untuk menjadi acuan bagi kota-kota lainnya dalam hal pembangunan kota menuju kota cerdas (smart city) (Suhendra, 2017).

Kota Pekanbaru sendiri, yang menjadi fokus kajian dari penulis adalah salah satu kota yang secara definitif jika merujuk pada berbagai indikator yang dikemukakan Firdaus dalam (Frebiyan, 2015) adalah kota metropolitan, yang bukan hanya wilayahnya yang luas akan tetapi sekaligus penduduknya juga melimpah, terbukti dari jumlah penduduk yang mencapai angka di atas satu juta jiwa (Frebiyan, 2015). Adalah menjadi menarik bagi penulis untuk meneliti tentang program terbaru daripada pemerintah kota Pekanbaru yaitu; "Kartu Smart Madani" dan "Kartu Identitas Anak" (Akn, 2019). Oleh karena selain Pekanbaru sejak tahun 2016 tengah gencar menuju pembangunan smart city sendiri, pada 2019 sendiri Pekanbaru sudah menjadi salah satu kota acuan bagi penerapan smart city dan kembali muncul dengan inovasinya melalui programnya yang menjadi objek penelitian penulis di sini.

Dengan melakukan penelitian ini, penulis mengharapkan mendapat sebuah atau suatu konsep tentang pengaruh dan juga penyebab diluncurkannya "Kartu Smart Madani" dan "Kartu Identitas Anak" oleh Pemerintah Kota Pekanbaru sebagai program pembangunan smart city di kota tersebut.

Di dalam penelitian yang dilakukan oleh (Akbar, 2018) ia menemukan bahwa bagaimana Pemerintah Kota Bandung melalui Renstra dan pengembangan Teknologi Informasi dan Komunikasi yang kemudian terealisasikan dalam bentuk pengembangan berbagai layanan di antaranya berbasis web, aplikasi dan lain sebagainya mampu meningkatkan partisipasi warga dalam memonitori dan memberikan gagasan seputar pemeliharaan dan pembangunan kota bandung. Lebih lagi, lewat fokus kajian tentang pemanfaatan 3 aplikasi di kota bandung dari sekian ratus aplikasi yang ada dan sedang dikembangkan kemudian lebih memudahkan pemerintah bandung untuk mengetahui aspirasi publik bandung (Akbar, 2018).

Selanjutnya menurut studi yang dilakukan oleh (Suhendra, 2017) mendapati bahwa Pengembangan Kota Cerdas dari kedua ibu kota daerah di barat dan timur Jawa ini, menurut penulis tak bisa dinyana bahwa layak menjadi bahan percontohan bagi kota-kota di seluruh penjuru Indonesia. Namun, penulis melihat bahwa ada masalah yang timbul dari konsep kota cerdas sendiri, alih-alih penerapannya. Yakni, belum adanya sebuah regulasi yang definitif dalam hal penerapan kota cerdas yang mana diharap menjadi suatu pedoman bersama dalam hal mewujudkan pembangunan kota cerdas ke depannya. Meskipun penulis berpendapat kiranya mesti ada sebuah regulasi yang nantinya berfungsi sebagai kerangka kerja daripada pembangunan dan penerapan kota cerdas, namun menurut pembaca itu tidak seperti pandangan penulis merupakan prasyarat yang sangat urgen dan kiranya dapat memberi 
manfaat signifikan dalam hal pembangunan ke depan, oleh sebab tingkat pemerataan infrastruktur, sosial kapital dan SDM yang dimiliki masing-masing kota tak bisa dinafikan berada pada tingkat perbedaan yang tinggi. Dan dengan demikian, jika kemudian regulasi tersebut diformulasi melalui contoh yang sudah ada barangkali akan berakibat bagi kota-kota yang tingkat pembangunannya paling bawah, beban pembangunan yang tinggi, seturut itu juga ada kesan ketergesa-gesaan didalamnya sehingga masyarakat pun dimungkinkan untuk merasakan dampaknya secara langsung. Belum lagi bagi pemerintah, bahwa di dalam birokrasi sendiri sesuai argumen penulis, perbedaan generasi sebelum era digitalisasi merupakan problem utama, dan itu bahkan terjadi di kedua kota percontohan di atas, bagaimana bila di daerah yang lain? Akibatnya tidak akan jauh berbeda dengan yang dirasa masyarakat luas, para pegawai tersebut yang kesusahan menyesuaikan diri akan dipacu bak kuda dalam lapangan pacu dan berpotensi memberi tekanan psikologi terhadap mereka yang tak bisa disangka.

Adapun temuan lainnya mengemukakan bahwa melalui penggunaan atau pemanfaatan saran dan prasarana Teknologi Informasi dan Komunikasi kota Jakarta dalam konteks pembangunan smart city dalam kurun waktu 3 tahun tercatat semenjak 2012 sampai 2015 mencapai kenaikan peringkat dalam evaluasi E Government. Bahkan, mampu mempertahankan posisinya di peringkat pertama kota yang berhasil mengaplikasikan E-Government dalam dua tahun terakhir. Penulis berkesimpulan bahwa penggunaan Teknologi Informasi dan Komunikasi mempunyai pengaruh yang cukup signifikan dalam pengembangan smart city di Jakarta (Tampubolon, 2016). Selanjutnya ada juga temuan mengenai bagaimana sosialisasi terkait smart city serta programprogramnya kepada publik di mana dari penelitian ini diketahui bahwa dari beberapa komponen perencenaan komunikasi dinas atau SKPD yang mengurus perihal informasi. Terdapat beberapa kekurangan di sana-sini. Utamanya penggunaan internet yang masih kurang dipahami oleh pihak pemerintah dan dalam hal komunikasi serta sosialisasi dinilai oleh penulis akan sangat kompatibel jika diadakan pertemuan langsung (tatap muka) ketimbang mensosialisasikan informasi bersandar pada Website pemerintah dan akun media sosial semata-mata (Annisa Citra Triyandra, 2017).

Terakhir ada penemuan terkait bagaimana memanfaatkan Teknologi Informasi dan Komunikasi dalam pengembangan smart city di Kota Makassar yang dilakukan oleh (Amri, 2016) di mana temuannya menjelaskan dengan menakar bagaimana TIK dimanfaatkan di kota Makassar, penulis kemudian mendapati banyak kekurangan dalam hal pengembangan Makassar sebagai smart city sekaligus Kota Dunia yang mempuni dalam berbagai komponen smart city sendiri. Mulai dari kekurangan dalam hal pemusatan data, di mana semua data-data yang berada di setiap skpd tidak saling terkoneksi atau terintegrasi dalam satu bank data, sumber daya manusia yang kemudian belum bisa menyesuaikan diri dengan laju perkembangan di era digital dan internet saat ini, sampai pada regulasi tentang TIK yang belum ada, seturut dengan itu sarana dan prasarana TIK yang kiranya dapat mendukung terealisasikan hal tersebut kurang. 


\section{METODE PENELITIAN}

Penelitian ini menggunakan pendekatan deskriptif-kualitatif yang mana mengusung sebuah studi pustaka (Creswell, 2010). Di mana penelitianpenelitian terdahulu dijadikan sebuah sumber sandaran penulis dalam menelaah dan menjawab rumusan masalah yang telah dikemukakan. Selain itu, penulis juga menjadikan artikel, berita dan website pemerintah sebagai bahan rujukan lainnya guna menakar valid tidaknya sebuah data yang didapat penulis dari sumber yang lain. Untuk menganalisis permasalahan yang ada digunakan kerangka teoritis antara lain formulasi kebijakan publik.

Kebijakan publik sendiri didefinisikan oleh Dye dalam (Sholih Muadi., Ismail MH., 2016) adalah apa yang kemudian diambil sebagai sebuah keputusan bagi pemimpin. Di mana menurut (Sholih Muadi., Ismail MH., 2016) sendiri kebijakan publik akan menjurus pada bagaimana siklus kebijakan sendiri terbentuk. Di mana siklus kebijakan sendiri menurut Parsons dalam (Sholih Muadi., Ismail MH., 2016) berputar dalam apa yang dikatanya formulasi kebijakan atau bagaimana kebijakan itu ditimbang sebelum dibuat; implementasi kebijakan atau penerapan dan pengaplikasian kebijakan yang sudah dibentuk di lapangan; dan terakhir, evaluasi kebijakan atau bagaimana bagian ini menjadi alat ukur keberhasilan daripada kebijakan yang telah dirumuskan dan diaplikasikan sebelumnya. Dengan begitu penulis, akan menggunakan ketiga kerangka pikir tersebut dalam menelaah permasalahan paper ini selanjutnya.

\section{HASIL DAN PEMBAHASAN}

Kota Pekanbaru terhitung semenjak tahun 2016 sudah dengan gencar mengampanyekan tentang konsep smart city atau kota pintar yang bakal dijadikan arah daripada pembangunan kota Pekanbaru sendiri. Hal tersebut terbukti daripada ungkapan yang diberikan oleh Walikota Pekanbaru pada waktu diwawancarai oleh salah satu media online lokal (Ansam, 2016) bahwa dia dengan tegas dan sungguh-sungguh ingin menjalankan smart city di Pekanbaru. Lebih jauh, Pekanbaru sendiri pada awalnya menjadikan salah satu kecamatannya menjadi salah satu daerah acuan atau percontohan untuk penerapan smart city secara lebih lanjut lagi (Ansam, 2016).

Seiring berjalannya waktu, semenjak saat itulah Pekanbaru hari demi hari mulai menerapkapkan smart city secara lebih jauh dan lebih jauh lagi. Dan tak ayal pada 2019 baru-baru ini kemudian Pekanbaru sendiri menjadi salah satu kota percontohan atau sebagai acuan dari setiap kota lain dalam hal menerapkan smart city sendiri di kota mereka masing-masing (Shofa, 2019). Selain itu, sudah semenjak tahun 2018 lalu, Pekanbaru sendiri sudah dicanangkan menjadi kota yang akan menjadi role model (Kim, 2018). Di mana hal tersebut, terkait erat dengan pemanfaatan Teknologi Informasi dan Komunikasi yang tengah dijalankan dan akan dijalankan oleh pemerintah Kota Pekanbaru dalam beberapa waktu setelahnya (Kim, 2018). Yang dimaksud dengan yang penulis sebutkan belakangan adalah bagaimana Pekanbaru akan memberi acuan kepada kota-kota lainnya dalam hal penerapan "Kartu Smart Madani" (Kim, 2018).

Kemudian, akhirnya pada tahun 2019 program terbaru daripada pemerintah kota Pekanbaru yaitu; "Kartu Smart Madani" dan "Kartu Identitas 
Anak" (Akn, 2019) secara resmi diluncurkan. Dengan menggembleng atau mengikutsertakan Bank Indonesia dan Bank Nasional Indonesia dalam penerapan program ini pihak pemerintah Kota Pekanbaru menaruh sekian harapan dalam proses pengaplikasiannya ke depan (R02, 2019). Program ini pun masih dalam tahap percobaan yang kemudian mengambil salah satu sekolah di Pekanbaru sebagai tempat pengaplikasian pertama untuk menakar seberapa jauh program ini dapat bermanfaat bagi perkembangan smart city dan digitalisasi di Kota Pekanbaru secara utuh (R02, 2019).

Walikota Pekanbaru dengan inovasinya terkait kedua kartu pintar tersebut kemudian berargumen bahwa fungsi daripada kedua kartu tersebut bukan hanya sebagai tanda pengenal semata, namun lebih dari itu, mengikuti perkembangan zaman yang ada di mana digitalisasi kian gencar merongrong setiap sendi kehidupan generasi " $Z$ " atau yang seringkali disebut dengan generasi milenial ini, maka kehadiran kedua kartu itu juga ditujukan untuk memudahkan setiap pelayanan publik yang ada di Pekanbaru secara umum, dan secara khusus bagi generasi yang saya sebut belakangan (R02, 2019).

Hal tersebut juga sejalan dengan apa yang kiranya disampaikan oleh (Amri, 2016) bahwa dengan memanfaatkan penerapan TIK dalam menjalankan pembangunan, tak ayal itu secara signifikan memberi kontribusi pada perkembangan smart city. Sebagaimana yang dilakukan oleh (Tampubolon, 2016) dalam menilai Jakarta dalam kurun waktu tiga tahun pengembangan saran dan prasarana TIK di sana, pun secara signifikan dan konsisten Jakarta mampu mempertahankan predikatnya sebagai salah satu kota dengan pembangunan smart city atau kota pintar yang paling terdepan di Indonesia selain Bandung, Surabaya dan Makassar.

\section{Formulasi Kebijakan}

Seperti yang dikemukakan oleh (Sholih Muadi., Ismail MH., 2016) bahwasanya formulasi kebijakan atau bisa juga disebut dengan perumusan kebijakan, tidak hanya berbicara tentang bagaimana kebijakan itu diambil oleh para perumus kebijakan. Oleh karena suatu pengambilan atau penentuan kebijakan sendiri tidak akan lepas daripada nilai-nilai yang, menurut William Dunn sendiri, sudah menjadi atau bisa dikatakan bersifat pra-kesadaran (Sholih Muadi., Ismail MH., 2016). Selain itu, jika kita merujuk pada pendapat lain yang kemudian dikemukakan oleh para ahli dalam bidang ini maka akan kita ketahui bahwa dalam tahap pengambilan kebijakan sendiri tidak akan terlepas daripada asumsi-asumsi, jika bukan sebagai bias yang timbul daripada pembacaan para perumus atau pembuat kebijakan sendiri (dalam hal ini pemerintah) (Sholih Muadi., Ismail MH., 2016). Sehingga dibutuhkan suatu cara yang dikira efektif untuk menambal kemungkinan-kemungkinan bias dan asumsi menyeleweng dalam tahap perumusan kebijakan sendiri timbul.

Oleh karena itu, William Dunn dan para ahli bidang kebijakan publik sendiri sudah mengemukakan bahwa dalam perumusan kebijakan yang, terhitung sejak dini, mestinya kalau tidak dikatakan hukumnya wajib untuk melibatkan beberapa elemen lain daripada masyarakat atau publik (Sholih Muadi., Ismail MH., 2016). Lebih jauh, mereka mengingatkan kita bahwa dalam hal pemutusan sebuah kebijakan sendiri atau bisa dikata perumusannya dapat kita tengok contohnya bagaimana tingkat kekompleksannya di tingkat pemecahan masalah yang ada pada organisasi-organisasi kecil, atau birokrasi pemerintahan kalau tidak secara langsung dikemukakan. Maka dari itu 
kemudian, kita menjadi wajib untuk mengetahui bagaimana cara kerja atau tindakan yang diambil oleh para pemutus atau perumus kebijakan di Kota Pekanbaru dalam hal merumuskan "Kartu Smart Madani" serta "Kartu Identitas Anak" sebagai sebuah program yang kiranya akan membantu pengembangan kota pintar (smart city) di sana, sehingga dengan begitu kita bisa melihat lebih lanjut bagaimana implementasi atau penerapannya sampai pada tahap bagaimana kita mengevaluasi program tersebut, dalam hal ini mengevaluasi bagaimana urgensinya terhadap masalah-masalah strategis yang muncul sebelumnya di kota Pekanbaru sendiri.

Merujuk pada bab empat Rencana Pembangunan Jangka Menengah (RPJM) (Bappeda Kota Pekanbaru, 2017) Kota Pekanbaru tahun 2017 sampai tahun2022 bahwa disitu diuraikan secara mendetail perihal permasalahan atau urusan-urusan yang mendesak untuk kemudian diambil tindakan perbaikan dan pembangunannya yang dalam konteks ini pemerintah kota sedikit banyak memberi kita cara masuk untuk menelaah lebih ekstensif bagaimana pemutusan program kerja atau program dua kartu pintar tersebut menjadi urgen atau dibutuhkan oleh publik atau masyarakat kota Pekanbaru. Sehingga menyebabkan program tersebut diluncurkan dalam tenggat waktu yang cukup singkat setelah ada wacana tentang hal yang sama kurang dari satu tahun belakangan (Kim, 2018). Adalah menjadi penting kiranya hal-hal yang disebutkan dalam Rencana Pembangunan Jangka Menengah (RPJM) (Bappeda Kota Pekanbaru, 2017) Kota Pekanbaru untuk menjadi petunjuk jalan (guide) bagi kita untuk menakar sejauh mana hal-hal tersebut berpengaruh terhadap proses perumusan permasalahan yang kelaknya ini terealisasi dalam program dua kartu pintar di Pekanbaru.

Pertama, dalam RPJM (Bappeda Kota Pekanbaru, 2017) Pekanbaru sendiri tercantum bahwa dalam hal pendidikan di sana menurut identifikasi pemerintah tengah menghadapi masalah lamanya atau usia pendidikan yang masih kurang, dan bukan hanya itu, seturut dengan itu menganga lebar. Terlihat bahwa dalam hal ini memang kebijakan program dua kartu pintar ini kiranya tidak menyeleweng dari apa yang tengah dihadapi kota Pekanbaru yang mana sudah diuraikan dalam dokumen RPJM (Bappeda Kota Pekanbaru, 2017) tersebut. Ditambah lagi penerapan program ini secara perdana ditetapkan pada sebuah sekolah di kota Pekanbaru sendiri yang menjadi sangat identik dengan tujuan pembangunan di dalam pendidikan sendiri (Akn, 2019).

Kedua, dalam RPJM (Bappeda Kota Pekanbaru, 2017) Pekanbaru sendiri pula tercantum yakni dalam hal pemanfaatan dan pemakaian teknologi dalam mendayagunakan perubahan dalam birkorasi masihlah tersendat-sendat. Lebih jauh, mengenai bagaimana penggunaan atau pemakaian internet yang mana di dalam birokrasi sendiri secara khusus dan dalam masyarakat secara umum, di mana menurut Walikota terjadi jurang kecakapan terhadap generasi sebelumnya dengan saat ini, tak ayal jika merujuk pada apa yang kemudian dikemukakan oleh (Amri, 2016) dan (Tampubolon, 2016) secara teoritis mempunyai pengaruh dalam merubah hal tersebut atau tindakan tersebut. Guna untuk lebih memberi penyesuaian kepada para birokrat atau masyarakat secara umum untuk secara lebih menarik menggunakan teknologi atau TIK yang saat ini memang menjadi jantung daripada pengembangan smart city sendiri. 


\section{Implementasi Kebijakan}

Pada tahapan implementasi ini menurut (Sholih Muadi., Ismail MH., 2016) adalah bagaimana ditahap formulasi atau tahap perumusan sendiri sudah didapat apa yang hendak dibuat dalam merealisasikan atau memperbaiki setiap kendala atau permasalahan yang ada, sedangkan pada tahap implementasi sendiri yang akan ditakar adalah bagaimana terealisasinya atau jalannya program atau kebijakan yang sudah ditetapkan sebelumnya oleh para perumus kebijakan. Jika kita merujuk pada pendapat yang kemudian dikemukakan oleh para ahli dalam bidang ini maka akan kita ketahui bahwa dalam tahap pengambilan kebijakan sendiri tidak akan terlepas daripada asumsi-asumsi, jika bukan sebagai bias yang timbul daripada pembacaan para perumus atau pembuat kebijakan sendiri (dalam hal ini pemerintah) (Sholih Muadi., Ismail MH., 2016). Sehingga dibutuhkan suatu cara yang dikira efektif untuk menambal kemungkinan-kemungkinan bias dan asumsi menyeleweng dalam tahap pengimplemaentasian kebijakan sendiri itu timbul.

Pertama yang perlu dilihat daripada implementasi yang mana itu merupakan realisasi dari program kota Pekanbaru atau lebih tepatnya program walikota Pekanbaru yang merupakan respon terhadap berbagai masalah dan kendala yang ada atau dihadapi kota Pekanbaru ialah bagaimana program dua kartu pintar "Kartu Smart Madani" dan "Kartu Identitas Anak" tersebut sesuai tidak dengan apa yang telah dirumuskan sebelumnya. Adalah nyata bahwa pada tahap implementasi tersebut dilibatkan beberapa pihak (stakeholder) untuk mewujudkan dan memajukan program yang telah dirumuskan oleh pemerintah kota (R02, 2019). Dengan melibatkan pihak sekolah sebagai tujuan utama sekaligus acuan perdana daripada pengembangan program kebijakan dua kartu pintar tersebut, maka secara gamblang memberikan sinyal bahwa dalam tahap implementasi sudahlah tepat sasaran program ini diterapkan.

Kedua, selain itu kelebihan yang kemudian dibuat oleh pemerintah kota Pekanbaru yakni dengan mengajak pihak swasta sendiri untuk berkolaborasi dalam mewujudkan pembangunan kota pintar di sana. Mereka yang dimaksud adalah pihak Bank Indonesia (BI) dan Bank Nasional Indonesia (BNI) yang dengan kedua kartu pintar itu turut memberikan sumbangsih, selain pemanfaatan teknologi di era digital saat ini, pihak swasta juga memberi semangat kepada pihak pemerintah kota dalam mewujudkan pelayan publik yang pintar (smart governance) dengan memanfaatkan keberadaan kedua kartu pintar tersebut (R02, 2019).

\section{Evaluasi Kebijakan}

Pada tahap sebelumnya sudah dijelaskan bagaimana kemudian program dua kartu pintar ini yang dikembangkan oleh pemerintah kota Pekanbaru secara baik dijalankan serta diterpakan di lapangan. Dengan berbagai cara untuk mendayagunakan segala sumber daya yang ada dan peluang yang barangkali mencuat ke permukaan setelah dicanangkannya program "Kartu Smart Madani" dan "Kartu Identitas Anak" yang menurut pemerintah berguna atau bernilai lebih daripada sekardar identitas untuk pemiliknya. Akan tetapi, dapat digunakan sebagai alat untuk mengakses layanan publik yang sudah disediakan oleh pemrintah kota hingga untuk menggunakannya dalam proses transaksi jual beli yang kiranya bisa membantu mempercepat kenaikan roda perekonomian di Kota Pekanbaru sendiri (Akn, 2019). 
Pertama, yang perlu dievaluasi daripada program atau kebijakan ini adalah bagaimana kemudian ini sejalan dengan apa yang diharapkan oleh RPJM kota Pekanbaru sendiri. Program yang dirumuskan ini kiranya jika kita merujuk pada pedoman atau petunjuk kita, yakni RPJM (Bappeda Kota Pekanbaru, 2017) kota Pekanbaru sendiri, maka kita akan menyimpulkan bahwa ini bukan sebuah program yang semestinya berdiri sendiri. Atau kalau tidak bukan sebuah program yang kemudian menjadi urgensi secara universal di kota tersebut. Bahwa kita menyadari betul permasalahan lingkungan dan tempat tinggal yang ada di sana, jangankan untuk dilihat dari perspektif atau cara pandang tempat tinggal cerdas (smart living) sendiri atau lingkungan pintar (smart environment). Dalam uraian RPJM (Bappeda Kota Pekanbaru, 2017) pun, yang di sini kita nilai sebagai sebuah uraian yang cukup komprehensif mengenai kekurangan, kendala dan permasalahan yang ada di sana tak ayal kita akan mempersoalkan kehadiran program dua kartu pintar ini, yang tampaknya hanya sebagai pemenuhan aspek teknologi belaka tanpa memerdulikan apa yang kiranya urgen atau penting dalam skala prioritas pembangunan kota menuju kota pintar (smart city).

Kedua, jika merujuk pada RPJM kembali (Bappeda Kota Pekanbaru, 2017) maka urusan atau permasalahan kemiskinan di kota tersebut terhitung cukup akut. Dan oleh karenanya pula menjadi patut untuk dipertimbangkan jalan demi jalan atau cara demi cara agar masyarakat kota tersebut bisa setidaknya bernafas atau lebih baik lagi terlepas dari jeratan kemiskinan. Dan melihat program ini, maksudnya dua kartu pintar ini, yang lebih menekankan proyek pelayanan berbasis online serta transaksi pelayanan sekaligus belanjaan melalui satu alat tersebut, ketimbang memberikan kontribusi terhadap masyarakat miskin kota, hal tersebut malah membuat mereka kian hari kian termarginalisasikan di kota tersebut, kalau tidak ingin mengatakan secara gamblang bahwa samasekali tidak memberikan kontribusi pada bagaimana memecahkan masalah kemiskinan yang masih berurat berakar di kota Pekanbaru sendiri.

\section{PENUTUP}

Setelah menguraikan dan menelaah tentang kehadiran program "Kartu Smart Madani" dan "Kartu Identitas Anak" di kota Pekanbaru maka penulis mencatat ada tiga hal yang didapat dari penelitian ini. Pertama, secara teoritis kehadiran program dua kartu pintar ini akan berdampak baik terhadap kecakapan atau literasi teknologi dan dayaguna informasi di kota Pekanbaru. Kedua, pengimplementasian daripada program dua kartu pintar ini kiranya sudah tepat sasaran jika merujuk kepada salah satu permasalahan yang dihadapi kota Pekanbaru. Ketiga dan terkahir, walaupun kehadiran program ini dalam beberapa hal baik adanya, namun di sisi lain terdapat lobang yang seharusnya lebih didahulukan untuk ditambal sebenarnya oleh pihak pemerintah kota melalui inovasi-inovasinya, salah satu contohnya bagaimana masyarakat miskin atau marginal di kota tersebut dapat didayagunakan lewat konsep kota pintar (smart city) dan pengembangannya di sana. 


\section{DAFTAR PUSTAKA}

Akbar, I. \& B. S. (2018). E-partisipasi dalam pembangunan lokal (studi implementasi. Jurnal Sosioteknologi, 8-12.

Akn. (2019). Wali Kota Pekanbaru Luncurkan Kartu Smart Madani dan KIA. Rabu, 16 Oktober 2019 - 13:29 WIB. Retrieved from https://daerah.sindonews.com/read/1449190/174/wali-kota-pekanbaruluncurkan-kartu-smart-madani-dan-kia-1571207384

Amri. (2016). ANALISIS PEMANFAATAN TEKNOLOGI INFORMASI DAN KOMUNIKASI DALAM MENUNJANG TERWUJUDNYA MAKASSAR SEBAGAI "SMART CITY." Jurnal Komunikasi KAREBA, 5(2).

Annisa Citra Triyandra. (2017). PERENCANAAN KOMUNIKASI DINAS KOMUNIKASI, INFORMATIKA, STATISTIK DAN PERSANDIAN KOTA PEKANBARU DALAM MENSOSIALISASIKAN PROGRAM SMART CITY. JOM VISIP, 4(2), 1-13.

Ansam, H. (2016). Pekanbaru Siap Menuju Smart City. Selasa, 23 Februari 2016 21:57 WIB. $\quad$ Retrieved from https://www.goriau.com/berita/baca/pekanbaru-siap-menuju-smartcity.html

Bappeda Kota Pekanbaru. (2017). Rencana Pembangunan Jangka Menengah 2017-2022 Kota Pekanbaru. Pekanbaru: Bappeda.

Creswell, J. W. (2010). Research Design: Pendekatan Kualitatif, Kuantitatif, dan Mixed. Yogyakarta: Pustaka Pelajar. Yogyakarta: Pustaka Pelajar.

Frebiyan, F. (2015). IMPLEMENTASI VISI KOTA PEKANBARU : PERWUJUDAN KEAMANAN DAN KETERTIBAN UMUM KOTA METROPOLITAN YANG MADANI TAHUN 2012-2015. JOM FISIP, 3(2), 1-13.

Kim. (2018). Pekanbaru Role Model Penerapan Smart City. Sabtu, 10 Maret 2018 15:10:00. Retrieved from https://www.inforiau.co/news/read/pekanbarurole-model-penerapan-smart-city-3332333034

R02. (2019). Kerjasama dengan BI dan BNI, Wali Kota Pekanbaru Launching Kartu Smart Madani dan KIA. SELASA,15 OKTOBER 2019 | 14:40:22 WIB. https://doi.org/10.17510/paradigma.v8i2.180

Shofa, J. N. (2019). Usung Smart City, Pekanbaru Jadi Kota Percontohan Indonesia. Senin, 4 November 2019 | 18:58 WIB. Retrieved from https://www.beritasatu.com/nasional/583531/usung-smart-citypekanbaru-jadi-kota-percontohan-indonesia

Sholih Muadi., Ismail MH., A. S. (2016). KONSEP DAN KAJIAN TEORI PERUMUSAN KEBIJAKAN PUBLIK Sholih Muadi. Ismail MH. Ahmad Sofwani. Jurnal Review Politik, 06, 195-224.

Suhendra, A. (2017). Kesiapan Pemerintah Daerah dalam Mewujudkan Kota Cerdas di Bandung dan Surabaya. Matra Pembaruan, 1(1), 1-9.

Tampubolon, L. P. D. (2016). PEMERINGKATAN E-GOVERNMENT INDONESIA (PEGI) DAN PEMANFAATAN TEKNOLOGI INFORMASI DI DKI JAKARTA. Jurnal Sistem Informasi (JSI), 8(2), 1121-1132. 